\title{
The hygiene and marketing of fresh cream as assessed by the methylene blue test
}

\author{
A Report by a Working Party* to the Director of the \\ Public Health Laboratory Service \\ With A NOTE BY HILARY MOGFORD \\ Epidemiological Research Laboratory, Central Public Health \\ Laboratory, Colindale, London, N.W.9
}

(Received 22 July 1970)

\section{SUMMARY}

The hygiene and marketing of fresh cream in England and Wales was investigated by a working party of the Public Health Laboratory Service (PHLS) between 1 October 1968 and 31 July 1969. Thirty-one cream-producing dairies were visited and observations made in the light of the Code of Practice published by the Milk and Milk Products Technical Advisory Committee of the Ministry of Agriculture, Fisheries and Food, and the Scottish Home and Health Department. Suggestions are made in this report to strengthen the code.

A total of 5184 samples of fresh cream comprising 4385 heat-treated, 282 clotted and 517 untreated were examined. Details of production, age of the cream, distance and mode of distribution along the retail chain were available for most samples, and this history was, as far as possible, related to the laboratory findings. In the laboratory the samples were examined by the methylene blue test, colony count, coliform and Escherichia coli I test and for pathogens. Staphylococcus aureus was grown from 59 out of 3417 samples of cream; 54 of these were from untreated cream. Phage typing indicated that a proportion of these strains were of animal, presumably bovine, origin. Other human pathogens isolated included one each of Salmonellatyphimurium, Brucella abortus, E. coli type 0126 and Clostridium welchii.

It appeared that heat-treated cream was much better, bacteriologically, than untreated; and that large dairies, in general, had better premises, more hygienic methods of preparation and the advantages of mechanical filling and capping of cartons; thus they offered the consumer a better product, bacteriologically, than some of the smaller dairies.

A statistical analysis of the results of the tests used showed the methylene blue

* Members of Working Party : Dr R. J. Henderson (Chairman, Worcester), Dr A. E. Wright (Secretary, Gloucester), Dr G. I. Barrow (Truro), Dr G. T. Cook (Guildford), Dr J. M. Croll (Lincoln), DrJ. V.Dadswell (Reading), Dr D. G. Davies (Carlisle), Mr H. C.Dawkins (Preston), Dr E. H. Gillespie (Sheffield), Dr Betty C. Hobbs (Colindale), Dr J. G. P. Hutchison (Birmingham), Dr Ruth C. J. James (Maidstone), Dr A. J. Kingsley Smith (Conway), Dr P. G. Mann (Bath), Dr W. Shepherd (Belfast City Hospital, N.I.), Dr G. H. Tee (Dorchester), Miss Joan M. Watkinson (Manchester), and Dr P. J. Wormald (Salisbury). Requests for reprints should be addressed to Dr A. E. Wright, Public Health Laboratory, Gloucestershire Royal Hospital, Southgate Street, Gloucester. 
test, in spite of some anomalies, to be of more use as a screening test than any of the others. As this test is cheap and easy to carry out, the working party thought that it should be the test of choice. In view of the known anomalies, however, the working party recommends that the test should remain a screening or advisory test and have no penal function. Results should be reported as follows: cream not decolorizing the dye in $4 \mathrm{hr}$. at $37^{\circ} \mathrm{C} .\left( \pm 0.5^{\circ}\right)$ after overnight incubation at $20^{\circ} \mathrm{C}$. $\left( \pm 0 \cdot 5^{\circ}\right)$ would be accepted as satisfactory; between $\frac{1}{2}$ and $4 \mathrm{hr}$. at $37^{\circ} \mathrm{C} .\left( \pm 0 \cdot 5^{\circ}\right)$ as fairly satisfactory; but if the dye were decolorized at the end of the overnight incubation the sample would be provisionally classified as 'unsatisfactory; requires further investigation'. A repeat sample would then be examined. If samples were repeatedly unsatisfactory, consultations would be arranged between the local authority, the laboratory and the dairy, with perhaps inspection of the dairy premises and retail storage conditions and further, more searching tests on samples made in an effort to eradicate production faults.

\section{INTRODUCTION}

In England and Wales the regulations for the sale of milk do not wholly apply to cream. Milk is so defined as to include cream in the Milk and Dairies (General) Regulations 1959, which deal with the hygienic preparation of milk, but not in the Milk (Special Designation) Regulations 1963 which deal with licensing and statutory tests. Although cream must therefore be produced under hygienic conditions, a licence to produce cream is not required nor are there any laboratory standards to which cream must conform.

Despite the few incidents of food poisoning associated with cream (Cockburn \& Simpson, 1954; Cockburn \& Vernon, 1955, 1960; Vernon, 1964, 1967, 1969), the lack of laboratory tests, the increase in the volume of cream consumed as fresh cream (300 million cartons in 1968) and in cream cakes, and the known potential of cream as a medium for bacterial growth have caused disquiet to many bacteriologists.

A working party of the Public Health Laboratory Service (Report, 1958) examined fresh cream and found that, with the exception of creams pasteurized in the bottle, most creams examined were of poor bacteriological quality and were associated with a high degree of post-pasteurization contamination. Colenso, Court \& Henderson (1966) confirmed these findings, showing that no less than 137 out of 575 samples had counts in excess of a million colonies per ml. As approximately $95 \%$ of the 575 samples in this series had been heat-treated, the evidence for postpasteurization contamination was conclusive. Many similar studies have been reported (Barrow \& Miller, 1967; Barrow, Miller, Johnson \& Hingston, 1968; Hutchison, Barrow, Henderson \& Wright, 1968; Gerken, Coleman \& Winner, 1968.) In these investigations good correlation was obtained between the time of reduction of methylene blue and the presence of coliform organisms. There were, however, anomalies, and for that reason the trade has preferred to examine cream by total counts and by tests for coliforms. Davis (1969) also suggested this.

A code of Hygienic Practice for Cream (1967) stresses that cream for human consumption should be made safe by heat treatment and that precautions for the 
avoidance of contamination after treatment should be taken, but makes no reference to laboratory methods of determining the adequacy of heat treatment or to the avoidance of post-pasteurization contamination.

The effect of these publications coupled with the considerable increase in the consumption of cream in this country caused disquiet concerning the hygiene of this commodity. The PHLS therefore convened a Working Party whose terms of reference form the title of this paper and from whose report the substance of this paper is drawn. Laboratories participated from all over England, Wales and Northern Ireland, and between October 1968 and July 1969 a total of 5184 cream specimens were examined.

\section{MATERIAL AND METHODS}

When samples were collected the name and address of the producer was recorded together with the date of manufacture (if known), the date of receipt by the retailer, the type of container, and whether it bore a date of manufacture or code mark of any kind. The name and address of the retailer was also recorded, together with the method of conveyance from producer to retailer and the approximate length in road miles of the retail chain.

Members of the working party visited cream manufacturing dairies in their area to study the hygiene of the production methods employed and to inquire into the observance of the Code of Practice.

A total of 4385 heat-treated, 517 untreated and 282 clotted cream samples were examined. These were gathered over a wide area of England, Wales and Northern Ireland. Untreated cream formed a surprisingly large part (10\%) of the total amount of cream examined, with the highest proportion in the north-east of England. Clotted cream was almost entirely sampled by one laboratory in Truro.

The methylene blue reduction test, total count and coliform count were carried out as described in Report (1958).

The classification used for the identification of coliform organisms was that recommended by the Coli-aerogenes Subcommittee of the Society for Applied Bacteriology (Report, 1956).

For the purposes of the investigation, anomalous results (Jenkins \& Henderson, 1969) were defined as decolorization of methylene blue immediately, with a colony count of less than $10^{4}$ colonies $/ \mathrm{ml}$., and failure to decolorize methylene blue in $4 \mathrm{hr}$. with a colony count of more than $10^{5}$ colonies $/ \mathrm{ml}$.

Samples were examined for salmonellas, brucellas, Staphylococcus aureus and other pathogens by the methods in use in each laboratory. Some laboratories undertook to carry out phosphatase tests on whole creams and creams diluted 1/10. A number of laboratories in addition carried out colony counts at $4,20-22,30$ and $35^{\circ} \mathrm{C}$. in addition to the customary $36 \pm 1^{\circ} \mathrm{C}$.

\section{RESULTS}

Table 1 shows the results of examination of 4385 heat-treated, 282 clotted and 517 untreated creams by the methylene blue test, colony counts, and presence in $0 \cdot 1 \mathrm{ml}$ of coliform organisms or $E$. coli I. 
In general, samples shown to be satisfactory by one test were also satisfactory by the other tests, and vice versa. Thus, few samples graded as satisfactory by the methylene blue test contained coliforms or $E$. coli $\mathrm{I}$ in $0.1 \mathrm{ml}$. and few gave colony counts exceeding $10^{5} / \mathrm{ml}$. Many samples graded as unsatisfactory by the methylene blue test contained coliforms or $E$. coli I in $0.1 \mathrm{ml}$. and many such samples gave colony counts exceeding $10^{5} / \mathrm{ml}$.

Table 1. Comparison of the methylene blue test, the coliform test, and colony counts on 4385 samples of heat-treated, 282 samples of clotted, and 517 samples of untreated cream

\begin{tabular}{|c|c|c|c|c|c|}
\hline \multicolumn{6}{|c|}{ (Figures in parentheses are percentages.) } \\
\hline & \multicolumn{5}{|c|}{$\begin{array}{l}\text { Time (hr.) to decolorize methylene } \\
\text { blue, and category according to the } \\
\text { methylene blue test }\end{array}$} \\
\hline & No. & $\begin{array}{c}>4 \\
\text { satis- } \\
\text { factory }\end{array}$ & $\begin{array}{c}\frac{1}{2}-4 \\
\text { fairly } \\
\text { satis- } \\
\text { factory }\end{array}$ & $\begin{array}{c}0 \\
\text { unsatis- } \\
\text { factory }\end{array}$ & $\begin{array}{l}\text { Total, } \\
\text { all cate- } \\
\text { gories }\end{array}$ \\
\hline Heat-treated & 4385 & $2283(52)$ & $936(21)$ & $1166(27)$ & - \\
\hline Clotted & 282 & $185(66)$ & $70(25)$ & $27(10)$ & - \\
\hline Untreated & 517 & $93(18)$ & $222(42)$ & $202(39)$ & - \\
\hline \multicolumn{6}{|c|}{ Coliforms in $0.1 \mathrm{ml}$. } \\
\hline Heat-treated & 4385 & $160(7)$ & 319 & $762(65)$ & $1241(28)$ \\
\hline Clotted & 282 & 32 (17) & $33(47)$ & $16(59)$ & $81(29)$ \\
\hline Untreated & 517 & $17(18)$ & $111(50)$ & $174(86)$ & $302(58)$ \\
\hline \multicolumn{6}{|c|}{ Escherichia coli I in $0.1 \mathrm{ml}$. } \\
\hline Heat-treated & 4385 & $13(<1)$ & $62(7)$ & $136(12)$ & $211(5)$ \\
\hline Clotted & 282 & $21(11)$ & $28(40)$ & $9(33)$ & $58(20)$ \\
\hline Untreated & 517 & $5(5)$ & $51(23)$ & $93(46)$ & $149(29)$ \\
\hline \multicolumn{6}{|c|}{ Colony counts* per ml. $\leqslant 10^{3}$} \\
\hline Heat-treated & 4385 & $1739(76)$ & $329(35)$ & $74(6)$ & $2142(49)$ \\
\hline Clotted & 282 & $131(71)$ & $27(39)$ & $7(26)$ & $165(59)$ \\
\hline Untreated & 517 & $40(43)$ & $31(14)$ & $5(3)$ & $76(15)$ \\
\hline \multicolumn{6}{|c|}{ Colony counts* per ml. $>10^{5}$} \\
\hline Heat-treated & 4385 & $81(4)$ & $177(19)$ & $734(63)$ & $992(23)$ \\
\hline Clotted & 282 & $22(12)$ & $15(21)$ & $13(48)$ & $50(18)$ \\
\hline Untreated & 517 & $5(5)$ & $70(32)$ & $153(76)$ & $228(44)$ \\
\hline
\end{tabular}

This general finding applied to heat-treated, clotted and untreated creams. $E$. coli I was, however, found in more samples of clotted cream $(20 \%)$ than of heat-treated cream $(5 \%)$.

Untreated creams were clearly inferior in bacteriological quality to heat-treated and clotted creams. Fewer samples had colony counts of less than $10^{3} / \mathrm{ml}$, and more contained coliforms and $E$. coli $\mathrm{I}$ in $0.1 \mathrm{ml}$. 


\section{Marketing}

Tables 2-4 illustrate aspects of marketing and the effects of various conditions upon colony counts and coliform content. In Table 2 the results are grouped according to the season of the year. Colony counts, the coliform content and percentage of samples containing $E$. coli I of heat-treated and untreated cream rose as the mean monthly atmospheric temperature rose from its lowest level of $1 \cdot 1^{\circ} \mathrm{C}$. in February to its highest of $17 \cdot 5^{\circ} \mathrm{C}$. in July.

Table 2. Fresh cream samples: total colony counts, coliform counts and Escherichia coli I counts with seasonal differences

(Figures in parentheses are percentages.)

\begin{tabular}{|c|c|c|c|c|c|c|}
\hline & \multicolumn{3}{|c|}{$\begin{array}{l}\text { October-March } \\
\text { inclusive }\end{array}$} & \multicolumn{3}{|c|}{$\begin{array}{l}\text { April--July } \\
\text { inclusive }\end{array}$} \\
\hline & $\begin{array}{l}\text { Heat- } \\
\text { treated }\end{array}$ & $\begin{array}{l}\text { Un- } \\
\text { treated }\end{array}$ & clotted & $\begin{array}{l}\text { Heat- } \\
\text { treated }\end{array}$ & $\begin{array}{l}\text { Un- } \\
\text { treated }\end{array}$ & clotted \\
\hline Total & 2268 & 228 & 215 & 2117 & 289 & 67 \\
\hline $\begin{array}{l}\text { With coliforms } \\
\text { in } 0.1 \mathrm{ml} \text {. }\end{array}$ & $560(25)$ & $114(50)$ & $60(28)$ & $703(33)$ & $184(64)$ & $21(31)$ \\
\hline $\begin{array}{l}\text { With } E \text {. coli I } \\
\text { in } 0.1 \mathrm{ml} .\end{array}$ & $81(4)$ & $57(25)$ & $42(20)$ & $130(6)$ & $92(32)$ & $14(21)$ \\
\hline \multicolumn{7}{|c|}{ With colony counts* of: } \\
\hline$\leqslant 10^{3}$ & $1227(54)$ & $33(15)$ & $124(58)$ & $915(43)$ & $43(15)$ & $41(61)$ \\
\hline$>10^{3}-10^{5}$ & $607(27)$ & $110(48)$ & $51(24)$ & $644(30)$ & $103(36)$ & $16(24)$ \\
\hline$>10^{5}$ & $434(19)$ & $85(37)$ & $40(19)$ & $558(26)$ & $143(50)$ & $10(15)$ \\
\hline
\end{tabular}

Since organisms multiply more quickly in warm weather than in cold, coliforms perhaps present in too small numbers or not multiplying fast enough to be detected in the winter readily show their presence in the warm months. Although in the tables the highest counts are recorded as $10^{5}$, counts as high as $4 \times 10^{7}$ to $2 \times 10^{9} / \mathrm{ml}$. were not infrequent expecially in untreated samples.

The results of counts carried out at different temperatures are not recorded in the tables. Colony counts at $4^{\circ}, 20-22^{\circ}$ and $30^{\circ} \mathrm{C}$. were on many occasions considerably higher than those recorded in the same samples incubated at $36 \pm 1^{\circ} \mathrm{C}$. This was noted in particular when the predominant flora consisted of Pseudomonas spp. This is doubtless the explanation of the anomalous result, occasionally experienced, that some samples with colony counts of $10^{3}$ fall into the class 'unsatisfactory' or 'fail' by the methylene blue test. Counts from such samples after incubation at $4^{\circ}$ or $22^{\circ} \mathrm{C}$. were sometimes surprisingly high.

Table 3 relates colony counts to the day of sampling. Counts in winter did not show much change until the fifth day and after. In summer the percentage of samples with counts of more than $10^{5} / \mathrm{ml}$. rose steadily from the day of manufacture.

Table 4 deals with the effect on the colony count of the type of carriage, distance carried and manner of storage for retailing. Unrefrigerated vehicles, e.g. milk floats, were in general use on milk rounds. Carriage of cream over long distances 
was usually in refrigerated transport. Some creams sent by rail were enclosed in insulated or cooled boxes; others were not, even on long journeys. In general, colony counts were higher in creams carried in unrefrigerated vehicles.

Table 3. Heat-treated cream: possible effect of age on colony counts

\begin{tabular}{|c|c|c|c|c|c|c|}
\hline & \multicolumn{6}{|c|}{ Day after manufacture when sample taken } \\
\hline & 0 & 1 & 2 & 3 & 4 & $\geqslant 5$ \\
\hline \multicolumn{7}{|c|}{ November-March } \\
\hline No. of samples & 93 & 322 & 279 & 195 & 136 & 195 \\
\hline \multicolumn{7}{|l|}{$\begin{array}{c}\% \text { showing colony } \\
\text { counts* of }\end{array}$} \\
\hline$\leqslant 10^{3}$ & 53 & 63 & 53 & 53 & 51 & 44 \\
\hline$>10^{3}-10^{5}$ & 29 & 21 & 26 & 29 & 30 & 25 \\
\hline$>10^{5}$ & 18 & 16 & 21 & 18 & 19 & 31 \\
\hline \multicolumn{7}{|c|}{ April--July } \\
\hline No. of samples & 77 & 365 & 338 & 199 & 125 & 164 \\
\hline \multicolumn{7}{|l|}{$\begin{array}{l}\% \text { showing colony } \\
\text { counts* of }\end{array}$} \\
\hline$\leqslant 10^{3}$ & 63 & 44 & 37 & 41 & 38 & 27 \\
\hline$>10^{3}-10^{5}$ & 30 & 32 & 37 & 28 & 30 & 27 \\
\hline$>10^{5}$ & 8 & 24 & 26 & 31 & 32 & 46 \\
\hline
\end{tabular}

Table 4. Marketing of heat-treated cream: possible effects on colony counts of type of carriage, distance carried, and type of retail storage

(Figures in parentheses are percentages.)

\begin{tabular}{|c|c|c|c|c|c|c|}
\hline \multirow[b]{3}{*}{ Type of vehicle } & \multicolumn{3}{|c|}{$\begin{array}{c}\text { Winter (Nov.-Mar.), } \\
\text { no. of samples }\end{array}$} & \multicolumn{3}{|c|}{$\begin{array}{c}\begin{array}{c}\text { Summer (Apr.-June), } \\
\text { no. of samples }\end{array} \\
\end{array}$} \\
\hline & \multirow{2}{*}{ Total } & \multicolumn{2}{|c|}{$\begin{array}{l}\text { With colony } \\
\text { counts } / \mathrm{ml} \text {. }\end{array}$} & \multirow{2}{*}{ Total } & \multicolumn{2}{|c|}{$\begin{array}{l}\text { With colony } \\
\text { counts } / \mathrm{ml} \text {. }\end{array}$} \\
\hline & & $\leqslant 10^{3}$ & $>10^{5}$ & & $\leqslant 10^{3}$ & $>10^{5}$ \\
\hline Refrigerated & 577 & $358(62)$ & $94(16)$ & 597 & $255(43)$ & $166(28)$ \\
\hline Unrefrigerated & 460 & $218(47)$ & $114(28)$ & 482 & $171(36)$ & $158(33)$ \\
\hline Insulated & 23 & $13(57)$ & $5(22)$ & 29 & $15(52)$ & $8(28)$ \\
\hline \multicolumn{7}{|c|}{$\begin{array}{l}\text { Distance transported } \\
\text { (miles) }\end{array}$} \\
\hline$\leqslant 50$ & 810 & $427(53)$ & $178(22)$ & 826 & $323(39)$ & $258(31)$ \\
\hline $51->200$ & 245 & $162(66)$ & $27(11)$ & 291 & $119(41)$ & $74(25)$ \\
\hline \multicolumn{7}{|l|}{ Type of storage } \\
\hline Cooled & 1002 & $565(56)$ & $193(19)$ & 960 & $408(43)$ & $269(28)$ \\
\hline Uncooled & 63 & $24(38)$ & $22(35)$ & 149 & $34(23)$ & $63(42)$ \\
\hline
\end{tabular}

Some creams travelled distances of more than 200 miles. Winter samples travelling 50-200 miles yielded lower colony counts than those travelling much shorter distances, but in summer this difference was not so obvious. The explanation probably is that cream sent long distances is usually produced by the larger firms. The production methods of the larger firms are generally better than those of small 
dairies with local distribution. In addition, cream from larger firms is usually sent in refrigerated vehicles.

In retail shops most samples had been cooled in some manner or other. Most common was the 'cool display' in which cool air expelled upwards from a refrigerator circulated round a series of open shelves above the refrigerator. A large proportion of samples were kept simply in domestic refrigerators. In the larger dairies cream was kept in a 'walk-in' cold room. Little difference was seen in the colony counts of samples stored under these differing conditions. Rarely retail samples were found uncooled on open shelves, counters or market stalls, but such samples formed only a small percentage of samples examined. Both in winter and

\section{Table 5. Marketing of heat-treated creams: effect of storage at refrigerator temperature at source}

(Figures in parentheses are percentages.)

\begin{tabular}{|c|c|c|c|c|c|c|}
\hline \multirow{3}{*}{$\begin{array}{l}\text { Days } \\
\text { after } \\
\text { manu- } \\
\text { facture }\end{array}$} & \multirow{3}{*}{$\begin{array}{l}\text { No. } \\
\text { exam- } \\
\text { ined }\end{array}$} & & \multicolumn{4}{|c|}{ No. of samples with } \\
\hline & & \multicolumn{3}{|c|}{$\begin{array}{l}\text { Colony } \\
\text { counts of }\end{array}$} & \multirow{2}{*}{$\begin{array}{l}\text { Coli- } \\
\text { forms } \\
\text { in } \\
0.1 \mathrm{ml} .\end{array}$} & \multirow{2}{*}{$\begin{array}{c}E . \text { coli I } \\
\text { in } \\
0.1 \mathrm{ml} .\end{array}$} \\
\hline & & $\leqslant 10^{3}$ & $>10^{3}-10^{5}$ & $>10^{5}$ & & \\
\hline 0 & 118 & $58(49)$ & $45(38)$ & $15(13)$ & $44(37)$ & $8(7)$ \\
\hline 1 & 98 & $37(38)$ & $36(37)$ & $25(26)$ & $42(43)$ & $7(7)$ \\
\hline 2 & 32 & $10(31)$ & $18(56)$ & $4(13)$ & $15(47)$ & $3(9)$ \\
\hline 3 & 40 & $8(20)$ & $17(43)$ & $15(38)$ & $15(63)$ & $3(8)$ \\
\hline 4 & 32 & $6(19)$ & $15(47)$ & $11(34)$ & $15(47)$ & 0 \\
\hline$\geqslant 5$ & 25 & $10(40)$ & $9(36)$ & $6(24)$ & $14(56)$ & 0 \\
\hline
\end{tabular}

Table 6. Marketing of untreated cream: effect of age on colony counts and coliform content

(Figures in parentheses are percentages.)

\begin{tabular}{|c|c|c|c|c|c|c|}
\hline \multirow{2}{*}{$\begin{array}{l}\text { Days } \\
\text { after } \\
\text { manu- } \\
\text { facture }\end{array}$} & \multirow{2}{*}{$\begin{array}{l}\text { No. } \\
\text { exam- } \\
\text { ined }\end{array}$} & \multicolumn{3}{|c|}{$\begin{array}{l}\text { Colony } \\
\text { counts of }\end{array}$} & \multirow{2}{*}{$\begin{array}{c}\text { Coli- } \\
\text { forms } \\
\text { in } \\
0 \cdot 1 \mathrm{ml} .\end{array}$} & \multirow{2}{*}{$\begin{array}{c}E . \operatorname{coli} \mathrm{I} \\
\text { in } \\
0.1 \mathrm{ml} .\end{array}$} \\
\hline & & $\leqslant 10^{3}$ & $>10^{3}-10^{5}$ & $>10^{5}$ & & \\
\hline \multicolumn{7}{|c|}{ Winter } \\
\hline 0 & 28 & $1(4)$ & $16(57)$ & $11(39)$ & $14(50)$ & $10(36)$ \\
\hline 1 & 78 & $12(15)$ & $35(45)$ & $31(40)$ & $40(51)$ & $18(23)$ \\
\hline 2 & 75 & $11(15)$ & $41(55)$ & $23(31)$ & $40(53)$ & $19(25)$ \\
\hline 3 & 47 & 7 (15) & $18(38)$ & $22(47)$ & $20(43)$ & $10(21)$ \\
\hline Total & 228 & $31(14)$ & $110(48)$ & $87(38)$ & $114(50)$ & $57(25)$ \\
\hline \multicolumn{7}{|c|}{ Summer } \\
\hline 0 & 39 & $1(3)$ & $17(44)$ & $21(54)$ & $34(87)$ & $24(62)$ \\
\hline 1 & 123 & $16(13)$ & $50(41)$ & $57(46)$ & $76(62)$ & $34(28)$ \\
\hline 2 & 77 & $15(20)$ & $20(26)$ & $42(55)$ & $50(65)$ & $22(29)$ \\
\hline 3 & 50 & $7(14)$ & $6(12)$ & $37(74)$ & $37(74)$ & $18(36)$ \\
\hline Total & 289 & $39(14)$ & $93(32)$ & $157(54)$ & $197(68)$ & $98(34)$ \\
\hline
\end{tabular}


summer there were more cooled samples with counts below $10^{3} / \mathrm{ml}$. and fewer with counts exceeding $10^{5} / \mathrm{ml}$. than of uncooled samples.

Tables 5 and 6 show the effect of ageing on heat-treated and untreated creams. In general, the colony counts and proportion of heat-treated samples with coliforms or $E$. coli $\mathrm{I}$ in $0.1 \mathrm{ml}$. increased with age even when these creams were stored at refrigerator temperature.

Table 7. Hygiene and marketing of cream: comparison of samples from large and small dairies

(Figures in parentheses are percentages.)

\begin{tabular}{|c|c|c|c|c|}
\hline & \multicolumn{2}{|c|}{ Large dairies* } & \multicolumn{2}{|c|}{ Small dairies $\dagger$} \\
\hline & Winter & Summer & Winter & Summer \\
\hline Total samples & 1191 & 1071 & 1520 & 1402 \\
\hline \multicolumn{5}{|l|}{ No. of samples } \\
\hline $\begin{array}{l}\text { With coliforms } \\
\text { in } 0.1 \mathrm{ml} .\end{array}$ & $197(17)$ & $318(30)$ & $537(35)$ & $590(42)$ \\
\hline $\begin{array}{l}\text { With } E . \operatorname{coli} \text { I } \\
\text { in } 0.1 \mathrm{ml} .\end{array}$ & $28(2)$ & $51(5)$ & $152(10)$ & $186(13)$ \\
\hline $\begin{array}{l}\text { With colony } \\
\text { counts } / \mathrm{ml} \text { of } \\
\end{array}$ & & & & \\
\hline$>10^{3}-10^{5}$ & $258(22)$ & $\begin{array}{l}483(45) \\
318(30)\end{array}$ & $510(34)$ & $\begin{array}{l}516(37) \\
455(32)\end{array}$ \\
\hline$>10^{5}$ & $170(14)$ & $270(25)$ & $390(26)$ & 431 (31) \\
\hline
\end{tabular}

* Large dairies with good equipment, mechanical filling, wide distribution in refrigerated vehicles.

$\dagger$ Small dairies using hand filling and local distribution in unrefrigerated vehicles.

Exact information about the age of untreated cream was difficult to obtain. It appears that the distribution of untreated cream is mainly local, and it was unusual to find untreated samples distributed more than 25 miles from where they were made. Usually they were carried in unrefrigerated vehicles and sold within 3-4 days after production. Colony counts were in general higher than those in heat-treated samples.

Table 7 compares the results of samples produced by large and small dairies. Those from large dairies were in general of better quality as judged by all tests than those from small dairies.

\section{Bacterial multiplication in cream in the dairy and in the laboratory}

In one laboratory bacterial counts were compared on 86 samples of heat-treated cream, some being stored at $4^{\circ} \mathrm{C}$. in their original containers, others in sterile jars. A tenfold or greater increase was shown to take place in $73 \%$ and coliforms originally present in $25 \%$ were present in $57 \%$ by the tenth day and were often accompanied by $E$. coli I not detected in the original specimen. There was no significant difference between the results of samples in the producers' containers and in sterile jars. 
In other laboratories heat-treated cream was collected in sterile containers and examined in parallel after storage in the producer's cold room and in the laboratory refrigerator. Some 33 samples showed similar tenfold rises in bacterial counts over a period of 3-5 days. One specimen was split for storage at $4^{\circ} \mathrm{C}$. in the laboratory, in the cold room in the dairy and on the milk float. Each portion showed a 5-day count of $4 \times 10^{5}$ colonies/g. due to Pseudomonas fluorescens.

Other workers observed a similar increase in counts over a 5-day period, coliforms and E. coli. I too few in number to be detected originally appearing at the end of this time even when stored at $4^{\circ} \mathrm{C}$. In some instances counts rose from a few thousand to an excess of $12 \times 10^{5} / \mathrm{ml}$.

New cream cartons taken at random showed no evidence of serious bacterial contamination.

\section{Visits to cream-making dairies}

Thirty-one cream-making dairies were visited. Nine (small) dairies made less than 100 gal. of cream a week, sixteen (medium) made an average of 100-1000 gal. per week and six (large) an average of over 1000 gal. per week. Christmas, Easter and the soft fruit season increased production, causing some dairies to buy in cream and market it under their own name.

Not all dairies tested the milk for keeping quality on arrival and three stored it overnight at room temperature.

Not all methods of heat-treatment of cream were satisfactory, for in one mediumsized dairy the cream, in a churn, was immersed in a bath of hot water. In two other dairies, one medium and the other large, flash pasteurization was used without accurate control of time or temperature.

In one establishment it proved difficult to divert pasteurized milk to the separator without the milk flowing over the hands of the operator.

Temperatures of separation showed wide variation, from the small dairy which separated milk still warm from the cow to the majority who separated between $35-50^{\circ} \mathrm{C}$. The time taken during separation varied enormously but all producers then cooled and stored for $24 \mathrm{hr}$. to allow the cream to 'age'. Afterwards cartons were filled by jug or ladle and the lids applied by hand. All the large dairies, but only half of the medium-sized dairies, had mechanical fillers.

Code marks were not universally used and there seemed to be some reluctance to indicate that cream had been heat-treated. In addition to the sale of cartoned cream, some was sold in cans for subsequent redistribution into cartons in retail shops. This seems a most undesirable feature.

\section{Pathogens}

Staphylococcus aureus was isolated from 59 out of 3417 samples, 54 from untreated and 5 from heat-treated creams. Of 41 phage-typed, 5 were group I, 3 group III and 3 group IV; the remainder were mixed or untypable. This suggests that the strains were not all of human origin and some could be of animal, possibly bovine origin. Other pathogens isolated included Salmonella typhimurium, Brucella abortus type 1, Escherichia coli O126, all from untreated samples, and $\mathrm{Cl}$. welchii from a treated sample. 


\section{Phosphatase testing}

In Canada fresh cream must pass the phosphatase test, in Northern Ireland virtually all fresh cream is pasteurized and in Sweden fresh cream must be pasteurized. In this survey $90 \%$ of the samples had been heat-treated and the phosphatase test was passed by 2649 out of 2957 of the heat-treated and clotted creams. Sixty-nine $(2 \%)$ showed readings between 10 and $18 \mu \mathrm{g}$. of para-nitrophenol per ml. of cream. Two hundred ( $7 \%$ ) failed the test in excess of $42 \mu \mathrm{g}$. The role of reactivation of phosphatase was not studied. Barrow et al. (1968) have shown that failures in this test have sometimes led to the demonstration of inadequate heat-treatment, but with a few exceptions heat-treatment apparently was being carried out according to the recommendations of the Code of Practice.

\section{$A$ bacteriological standard for cream}

Standards in force in other countries include:

(1) Northern Ireland: pasteurized fresh cream, at source and within $24 \mathrm{hr}$. of manufacture, must be free of coliforms in $1 \mathrm{~g}$.; farm-bottled, untreated cream, must have a count of less than 50,000 colonies/g.

(2) Canada: retail fresh cream must pass the phosphatase test, be free of coliforms and have less than 50,000 organisms $/ \mathrm{ml}$.

(3) Sweden: fresh cream must be pasteurized, have a count of less than 100,000 organisms $/ \mathrm{ml}$, a coliform count not exceeding $10 / \mathrm{ml}$. and an aerobic spore count of less than $100 / \mathrm{ml}$.

Table 5 shows that of 118 samples of heat-treated cream refrigerated at source and examined within $24 \mathrm{hr}$. of manufacture, $37 \%$ would have been unacceptable under Northern Ireland standards. In fact $25 \%$ of all heat-treated creams yielded coliform organisms. Additionally, cream in storage even at refrigeration temperatures allowed coliforms and salmonellas (Colenso et al. 1966) to multiply.

Colony counts were also considered. In this survey $37 \%$ of untreated creams in winter and $50 \%$ in summer had counts exceeding $10^{5}$ colonies $/ \mathrm{ml}$. (Table 2). Of pasteurized creams $19 \%$ in winter and $26 \%$ of summer samples had counts in excess of $10^{5} / \mathrm{ml}$. All these would have failed the Canadian requirements. The Swedish regulations would have permitted a higher percentage of passes.

The application of a test for $E$. coli I shows a similar trend (Table 1). Of 5184 samples, $5 \%$ of heat-treated, $20 \%$ of clotted, and $29 \%$ of untreated would have been rejected. On the other hand (Table 8), acceptance of samples free of $E$. coli I would have permitted $25 \%$ of creams proved unsatisfactory by the methylene blue test to be marketed and an almost similar number (23\%) of those with colony counts in excess of $10^{5} / \mathrm{ml}$. Because of these observations the Working Party did not feel able to recommend any one of these three tests as suitable in itself for the statutory control of bacteriological quality of cream in the United Kingdom. For this reason it reconsidered the use of the methylene blue test as a clearance or screening test.

The results from all laboratories applying the methylene blue test are shown in Table 1, where it can be seen that $73 \%$ of all heat-treated creams are acceptable. 
Samples classed as satisfactory by the methylene blue test contain only $7 \%$ of samples with coliforms present and $4 \%$ with counts of over $10^{5} / \mathrm{ml}$. On the other hand, unsatisfactory samples contain a much higher percentage with coliforms and colony counts in excess of $10^{5} / \mathrm{ml}$. The test would fail $27 \%$ of heat-treated creams, the coliform test $28 \%$ and the colony count $23 \%$.

Table 8. Comparison of results of Escherichia coli I test with methylene blue reduction test, presence of coliforms, and colony counts

(Figures in parentheses are percentages.)

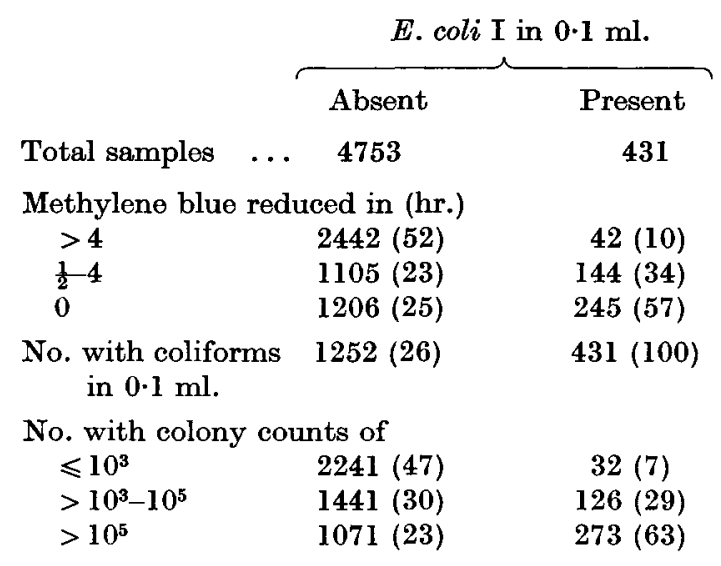

Examination of the anomalies showed that where creams with low colony counts at $37^{\circ} \mathrm{C}$. failed the methylene blue test, incubation at temperatures of $4^{\circ}$ or $20^{\circ} \mathrm{C}$. often revealed high colony counts. The converse anomaly where creams with high colony counts were satisfactory or fairly satisfactory with the methylene blue test was not explained. Nevertheless, the methylene blue test is a quick and easy test to perform and, as it bears a good correlation to other tests, the Working Party was of the opinion that it could serve excellently as a screening or advisory test provided the history of the specimen was known. Samples repeatedly found to be unsatisfactory would require further investigations with an inspection of dairy premises and retail storage conditions in an effort to eradicate production faults. In short, the methylene blue test is a good advisory test but it may not be used without further inquiry either to reject samples of cream or penalize a particular producer.

\section{Code of practice}

It appeared to the working party that dairy managers were in general putting into effect the recommendations in the Code of Hygienic Practice for the Preparation of Cream, issued in 1967 by the Ministry of Agriculture, Fisheries and Food, and the Scottish Home and Health Department. Only in one or two dairies was it clear that only lip service was paid to the code.

Suggestions for amendment of the Code were made as follows:

(1) The universal introduction of coding on cartons and bottles which could be clearly understood by traders and Public Health Inspectors. 
(2) The application of a screening test such as the methylene blue test as a pointer to unsatisfactory practice. The test to lead to further investigations if the results were repeatedly unsatisfactory.

(3) The elaboration of section IV of the code to include recommendations on the structure and texture of equipment and utensils together with detail on cleansing measures. Section vII should also be strengthened and the use of paper towels and the care of the hands should be mentioned. Clearer instructions should be given for personnel with injuries. The present recommendation to use waterproof dressings could be interpreted as an invitation to continue work whilst suffering from a septic lesion.

(4) In the final paragraph in the code attention is drawn to the fact that the code has no statutory force. Further, the paragraph contains a number of apologetic statements destroying the whole spirit of the code. This paragraph should be reworded much more firmly and be followed by an exhortation to conform to the recommendations of the code.

(5) The wording of much of the Code could be more definite. Even the use of the words 'pure', 'sweet', 'clean' and 'marketable' are open to objection and might be replaced by wholesome. It is doubtful if the word 'pure' can be applied to such a complex mixture as cream.

\section{DISCUSSION}

The working party has confirmed that bacterial counts on retail cream are frequently high and that in this respect unheated is worse than heated cream. Some cream is prepared under unhygienic conditions.

Amongst the potentially pathogenic organisms which were isolated, staphylococci, possibly of bovine origin, were largely from untreated cream. Although no ill effects were reported from the 59 samples from which Staphylococcus aureus was isolated, food-poisoning outbreaks have occurred due to contamination of cream or cream products with this organism. Other organisms isolated from unheated specimens included Salmonella typhimurium, Brucella abortus and Escherichia coli, thus confirming the importance of heat-treatment. Nevertheless cream producers should be aware of the dangers of post-pasteurization contamination. This danger is particularly important where small shopkeepers, having no connexion with dairying, buy cream in 1 gal. cans and carton it for sale. In one instance it was shown that this process introduced Staphylococcus aureus into the sample. Officers of local authorities can take action in such instances under the 1959 Milk and Dairy (General) Regulations but there is strong demand from Public Health Inspectors for cream to be included in the 1963 Milk (Special Designation) Regulations. So far as hygiene of premises and production is concerned, the 1959 Regulations are quite strong but are not sufficiently used.

The larger dairies have many advantages, including good supervision and equipment, suitable premises, mechanical filling and capping of containers. Additionally, their large output necessitates distribution over a wide area but this is done in modern refrigerated vehicles. The small producers on the other hand often prepared cream under unsuitable conditions and filled and capped the cartons by hand. 
Very often the smaller producer handled unheated cream and this was distributed locally, rarely exceeding a radius of 25 miles. Although the results reflected these differences, as may be seen in Table 7, not all small producers made poor cream, for some small family businesses were excellently run and produced cream of a consistently high quality.

Members of the working-party would like to invite the attention of cream producers to a particularly undesirable feature of cream, namely the presence of coliform organisms in a large number of heat-treated samples that have apparently been handled under reasonably good conditions. Loss of keeping quality soon after production might well be the only apparent result of the presence of large numbers of coliforms, but the presence of these organisms in heat-treated samples must surely indicate inadequate heat-treatment, unsterile equipment, contamination from the environment, unsatisfactory conditions of storage and distribution, or a combination of these. The working party thinks this practical problem is one to which the trade could address itself; its solution would be of obvious benefit to the trade and the consumer.

The working-party is of the opinion that the best hope of improvement in cream production lies in a Code of Practice suitably strengthened by the recommendations contained in this report.

Members of the working party are indebted to Mrs Ruth Homes of the Public Health Laboratory, Worcester, for her arduous work in collating and analysing the results, and all Public Health Inspectors, Sampling Officers, laboratory technicians and others who helped in the survey.

\section{REFERENCES}

BARRow, G. I. \& MiLleE, D. C. (1967). A bacteriological study of fresh cream and cream products in Cornwall. Monthly Bulletin of the Ministry of Health and the Public Health Laboratory Service 26, 254.

Barrow, G. I., Milleer, D. C., Johnson, D. L. \& Hingston, C. W. J. (1968). B. abortus in fresh cream and cream products. British Medical Journal ii, 596.

Cockburn, W. C. \& Simpson, E. (1954). Food poisoning in England and Wales, 1951-1952. Monthly Bulletin of the Ministry of Health and the Public Health Laboratory Service 13, 12.

CockBURN, W. C. \& Vernon, E. (1955). Food poisoning in England and Wales, 1954. Monthly Bulletin of the Ministry of Health and the Public Health Laboratory Service 14, 203.

Cockburn, W. C. \& Vernon, E. (1960). Food poisoning in England and Wales, 1959. Monthly Bulletin of the Ministry of Health and the Public Health Laboratory Service 19, 224.

Colenso, R., Court, G. \& Henderson, R. J. (1966). Fresh cream in Worcestershire: A bacteriological study. Monthly bulletin of the Ministry of Health and the Public Health Laboratory Service 25, 153.

Code of Hygientc Practice for the Preparation of Cream (1967). Issued by the Ministry of Agriculture, Fisheries and Food and the Scottish Home and Health Department.

DAvis, J. G. (1969). The microbiological examination of cream. Medical Officer 122, 115.

Gerken, A., Coleman, J. C. \& Winner, H. I. (1968). Bacteriological impurity of dairy-cream samples in London. Lancet i, 634.

Hutchison, J. G. P., Barrow, G. I., Henderson, R. J. \& Wright, A. E. (1968). The bacteriological quality of dairy cream. Lancet ii, 99.

Jenkins, H. R. \& Henderson, R. J. (1969). The source of bacteria in fresh cream, and the methylene blue reduction test as a guide to hygienic quality. Journal of Hygiene 67, 401. 
Milk and Datries (Generat) Regulations (1959). Statutory Instrument, 1959, no. 277. London. H.M.S.O.

Mitk (Special Designation) Regulations (1963). Statutory Instrument, 1963, no. 1571. London. H.M.S.O.

REPORT (1956). The nomenclature of coli-aerogenes bacteria. Report of the Coli-Aerogenes Sub-Committee of the Society for Applied Bacteriology. Journal of Applied Bacteriology 19, 108.

REPORT (1958). The bacteriological examination and grading of fresh cream. Report of a working party of the Public Health Laboratory Service. Monthly Bulletin of the Ministry of Health and the Public Health Laboratory Service 17, 77.

VerNon, E. (1964). Food poisoning in England and Wales, 1963. Monthly Bulletin of the Ministry of Health and the Public Health Laboratory Service 23, 189.

VERNON, E. (1967). Food poisoning in England and Wales, 1966. Monthly Bulletin of the Ministry of Health and the Public Health Laboratory Service 26, 235.

Vernon, E. (1969). Food poisoning in England and Wales, 1968. Public Health. London 83, 205.

\section{Statistical comparison between results from the methylene blue test and three other tests of the bacteriological quality of cream samples}

\section{BY HILARY MOGFORD}

The three tests of colony count, coliforms in $0.1 \mathrm{ml}$ and Escherichia coli I in $0 \cdot 1 \mathrm{ml}$. were each used in turn as a reference test. The findings of the methylene blue test were then compared with the reference test. The criteria for failing the four tests were 'unsatisfactory' to the methylene blue test, a colony count of more than 100,000 per $\mathrm{ml}$. at $36^{\circ} \mathrm{C}\left( \pm 1^{\circ}\right)$, coliforms found to be present in $0.1 \mathrm{ml}$, and $E$. coli I found in $0.1 \mathrm{ml}$. The tables divide up the three lots of cream samples according to whether or not they failed the methylene blue and reference tests (Tables 9-11).

The analysis aims at seeing how well the methylene blue test does compared with the other three. There are two ways in which the test under observation can fail to agree with the reference test. It can be insensitive and not fail all the samples failed by the reference test, and it can be non-specific and fail many of the samples which it should have passed. The following statistical indices were evaluated for each of the nine test pairs.

$a=$ sensitivity $=$ proportion of all samples failing the reference test which are failed by the methylene blue test.

$b=$ specificity $=$ proportion of all samples passing the reference test which are passed by the methylene blue test.

$J=$ Youden's Index (Youden, 1950) $=$ combined estimate of sensitivity and specificity. It lies between zero, if the test is doing no better than random, and 1 , if the test is producing exactly the same results as the reference test.

The standard error of $J$ is also given.

Throughout the tables the methylene blue test was more specific than sensitive, especially with the clotted-cream samples. This implies that it made a higher rate 
of mistakes in passing failures to the reference test than in failing samples which had passed the reference test.

The value of $J$, which assesses the overall agreement, shows up as highest between methylene blue test compared with the colony count and lowest with the

Table 9. Heat-treated cream: comparison of methylene blue test with other tests

\begin{tabular}{|c|c|c|c|c|c|c|c|}
\hline \multirow{2}{*}{$\begin{array}{l}\text { Methylene } \\
\text { blue test }\end{array}$} & \multirow{2}{*}{$\begin{array}{l}\text { No. of } \\
\text { samples }\end{array}$} & \multicolumn{2}{|c|}{ Colony count } & \multicolumn{2}{|c|}{ Coliforms in $0.1 \mathrm{ml}$. } & \multicolumn{2}{|c|}{ E. coli $\mathrm{I}$ in $0.1 \mathrm{ml}$. } \\
\hline & & $\mathbf{F}$ & $\mathbf{P}$ & $\mathbf{F}$ & $\mathbf{P}$ & $\mathbf{F}$ & $\mathbf{P}$ \\
\hline Failed & 1166 & 734 & 432 & 762 & 404 & 136 & 1030 \\
\hline Passed & 3219 & 258 & 2961 & 479 & 2740 & 75 & 3144 \\
\hline \multirow[t]{3}{*}{ Total } & 4385 & 992 & 3393 & 1241 & 3144 & 211 & 4174 \\
\hline & & \multicolumn{2}{|c|}{$\begin{aligned} a & =0.74 \\
b & =0.87 \\
J & =0.61\end{aligned}$} & \multicolumn{2}{|c|}{$\begin{aligned} a & =0.61 \\
b & =0.87 \\
J & =0.49\end{aligned}$} & \multicolumn{2}{|c|}{$\begin{aligned} a & =0.64 \\
b & =0.75 \\
J & =0.40\end{aligned}$} \\
\hline & & \multicolumn{2}{|c|}{ S.E. $(J)=0.02$} & \multicolumn{2}{|c|}{ s.E. $(J)=0.01$} & S.E. & $=0.03$ \\
\hline
\end{tabular}

Table 10. Clotted cream: comparison of methylene blue test with other tests

\begin{tabular}{|c|c|c|c|c|c|c|c|}
\hline \multirow{2}{*}{$\begin{array}{l}\text { Methylene } \\
\text { blue test }\end{array}$} & \multirow{2}{*}{$\begin{array}{c}\text { No. of } \\
\text { samples }\end{array}$} & \multicolumn{2}{|c|}{ Colony count } & \multicolumn{2}{|c|}{$\begin{array}{c}\text { Coliforms in } \\
0.1 \mathrm{ml} .\end{array}$} & \multicolumn{2}{|c|}{$\begin{array}{l}\text { E. coli. I } \\
\text { in } 0.1 \mathrm{ml} \text {. }\end{array}$} \\
\hline & & F & $\mathbf{P}$ & $\mathbf{F}$ & $\mathbf{P}$ & $\mathbf{F}$ & $\mathbf{P}$ \\
\hline Failed & 27 & 13 & 14 & 16 & 11 & 9 & 18 \\
\hline Passed & 255 & 37 & 218 & 65 & 190 & 47 & 208 \\
\hline \multirow[t]{3}{*}{ Total } & 282 & 50 & 232 & 81 & 201 & 56 & 226 \\
\hline & & \multicolumn{2}{|c|}{$\begin{aligned} a & =0.26 \\
b & =0.94 \\
J & =0.20\end{aligned}$} & \multicolumn{2}{|c|}{$\begin{aligned} a & =0.20 \\
b & =0.95 \\
J & =0.14\end{aligned}$} & \multicolumn{2}{|c|}{$\begin{aligned} a & =0.16 \\
b & =0.92 \\
J & =0.08\end{aligned}$} \\
\hline & & E. ( & 0.06 & s.E. $(J$ & 0.05 & S.E. $(J$ & 0.05 \\
\hline
\end{tabular}

Table 11. Untreated cream: comparison of methylene blue test with other tests

\begin{tabular}{|c|c|c|c|c|c|c|c|}
\hline \multirow{2}{*}{$\begin{array}{l}\text { Methylene } \\
\text { blue test }\end{array}$} & \multirow{2}{*}{$\begin{array}{c}\text { No. of } \\
\text { samples }\end{array}$} & \multicolumn{2}{|c|}{ Colony count } & \multicolumn{2}{|c|}{$\begin{array}{c}\text { Coliforms in } \\
0.1 \mathrm{ml} \text {. }\end{array}$} & \multicolumn{2}{|c|}{$\begin{array}{c}\text { E. coli I } \\
\text { in } 0.1 \mathrm{ml} \text {. }\end{array}$} \\
\hline & & F & $\mathrm{P}$ & $\mathbf{F}$ & $\mathbf{P}$ & $\mathbf{F}$ & $\mathrm{P}$ \\
\hline Failed & 202 & 153 & 49 & 174 & 28 & 93 & 109 \\
\hline Passed & 315 & 75 & 240 & 128 & 187 & 56 & 259 \\
\hline \multirow[t]{3}{*}{ Total } & 517 & 228 & 289 & 302 & 215 & 149 & 368 \\
\hline & & \multicolumn{2}{|c|}{$\begin{aligned} a & =0 \cdot 67 \\
b & =0 \cdot 83 \\
J & =0.50\end{aligned}$} & \multicolumn{2}{|c|}{$\begin{array}{l}a=0.58 \\
b=0.87 \\
J=0.45\end{array}$} & \multicolumn{2}{|c|}{$\begin{aligned} a & =0 \cdot 62 \\
b & =0 \cdot 70 \\
J & =0 \cdot 33\end{aligned}$} \\
\hline & & \multicolumn{2}{|c|}{ s.E. $(J)=0.04$} & \multicolumn{2}{|c|}{ S.E. $(J)=0 \cdot 04$} & S.E. $(0$ & $0 \cdot 05$ \\
\hline
\end{tabular}

$E$. coli I test. This held for all three types of cream sampled. Generally, the index is high for heat-treated samples but poor for clotted cream. In fact it does not differ significantly from zero for the methylene blue and $E$. coli I tests comparison.

Most cream samples encountered in laboratories are heat-treated and it is with 
this type that the methylene blue test proved to be the most promising as a potential screening test of bacteriological quality. It is likely to fail about three-quarters of the samples which would have colony counts of more than 100,000 per ml. and fail about one in eight of the samples with lower colony counts.

\section{REFERENCE}

YoUden, W. J. (1950). Index for rating diagnostic tests. Cancer 3, 32. 